ARTICLE

https://doi.org/10.1057/s41599-020-0411-x

\title{
Monsters and the pantomime
}

\author{
Robert Marsden (1D ${ }^{1 凶}$
}

\begin{abstract}
Monsters within British pantomime are ubiquitous creatures, from the ogre in the castle of Puss in Boots to the Giant at the top of the beanstalk, and as personified in the monstrous acts of Wicked Stepmothers, frightening Barons and diabolical henchmen. The popularity of pantomime means that it is often the first encounter that a child has with a monster in material form, sharing the same physical space: a theatre. Bruno Bettelheim (1991) argues that fairytales, from where many pantomimes are drawn, are our first negotiations with the monstrous. In pantomime, the audience are complicit in the act of finding, chasing and dealing with the monster, and the ethical positioning of this by writers and directors is paramount in guiding us to understand how we may deal with the 'other' in our own lives. This paper critically interrogates the threat posed by these monsters when invested with a materiality in performance. In the first instance, I explore the interplay between stage space and the representation of the monster and how this relates to my professional experience of directing over twenty-five professional pantomimes in the United Kingdom since 1999. Tracing this spatial dynamic between monster and audience to the medieval stage and the ludic dimension to the staging of the devils in the mystery play, the paper argues that there is a long-reaching historical antecedent to the staging of evil that informs and inspires spatial practices in modern-day pantomime. Key questions are: to what extent have pantomimes historically presented and rehearsed the threat posed by the monster in order to contain that threat?; What ethical considerations do producers, writers and directors now face in the contemporary pantomime? Finally, to what extent does the popular form of pantomime itself matter as a vehicle for enabling audiences both young and old to confront the monstrous Other?
\end{abstract}

\footnotetext{
${ }^{1}$ University of Staffordshire, Stoke on Trent ST4 2DE, UK. ${ }^{凶}$ email: r.j.marsden@staffs.ac.uk
} 


\section{Prologue: pantomime and 'otherness'}

quintessentially British phenomenon, the annual pantomime is at the theatrical heart of Christmas since its inception in 1716. Whilst now a British genre, pantomime was originally influenced by the dance drama (as opposed to logocentric work) of the Italian Night Scenes that visited Drury Lane from France in the early 18th Century and the stock plot structure and characters from the Italian commedia dell'arte, whose characters began to be woven into English drama from the sixteenth century. With over 250 professional productions presented across the United Kingdom in the 2019/20 Christmas season, pantomime shows no signs of slowing in popularity and with a limited amount of international presentations (those in Los Angeles and at the Joburg Theatre, South Africa for example), remains a British construct and sits within the field of 'popular theatre' in UK academia. One element has remained constant over its three hundred year history: at the heart of the story is the battle of 'good versus evil' and there is always a baddie to defeat in the guise of the 'other' or monster. This has manifested itself in terms of containing a threat or revealing a threat, through the storyline.

These 'others' manifest themselves in numerous guises, from the ogre in the castle of Puss in Boots, to the Giant at the top of the beanstalk in Jack and the Beanstalk and personified through the monstrous acts of Wicked Stepmothers, frightening Barons and diabolical henchmen. The sheer popularity of the pantomime genre means that it is often the first encounter that a child has with a monster in material form whilst sharing the same physical space: a theatre. Charting the monster's position in pantomime and how this has related to the staging of evil in pantomime and within theatre in general, the paper discusses how there is a negotiation for a child as they encounter personifications of 'otherness' for the first time at the pantomime and the ethical and moral responsibilities of the contemporary pantomime writer, director and producer are explored as part of the conclusion to this piece.

The theatre space becomes a socially sanctioned space for the creation of what Donald Winnicott (1971) describes as the third or potential space-a liminal play space created from the overlapping minds of the audience and actors. Bruno Bettelheim (1991) argues that fairy tales, from which pantomimes are often drawn, are our first negotiations with the monstrous and the liminal play space therefore becomes the home for these negotiations. As the pantomime monster is often (but not always) classed as an immortal character in the cast list, an immediate and explicit sense of their heightened power in the story is thereby manifested. They become larger than life, transcending conventional notions of time and space, can cast spells and even live on Cloudland. This power suggests that they can push against social norms; as do day to day 'monsters' (terrorists, fraudsters and murderers) who subvert society's moral, social, legal, religious or ethical codes. The ethical dilemma for contemporary manifestations of pantomime therefore relates to how we deal with the 'other'. Yet, one of our leading pantomime academics Millie Taylor banishes the dealing of vengeance to a brief footnote, stating that is does not occur as it is not politically correct. Rather, villains are magically made good, made to marry the Dame or banished' (2009, p. 90). This paper argues that the dealing of the 'other' and notions of revenge, vengeance or comeuppance should be forefronted through the lens of having a moral responsibility to an audience. With the paucity of critical exploration in this area, this paper aims to rebalance this.

Moreover, in addition to representing the potential literal existence and threat of monsters roaming the real world, pantomime monsters may also take on symbolic and allegorical meanings. The qualities that make a monster monstrous are therefore not limited to their possessing extraordinary powers, being physically deformed, disfigured or outsized; but may also be character driven. The Giant, for example, is all the more monstrous for being a greedy hoarder who wishes to own and consume everything, perhaps embodying something of a child's omnipotence. Similarly, themes of sexual voracity, revenge and a desire to dominate and control are present in the idea and staging of the monster. Through an expressionistic extension of the norm, the pantomime monster creates opportunities for children to softly and tacitly deal with 'otherness' within the safe context of a Christmas family event.

Drawing upon the thinking of key researchers and thinkers in the fields of fairytale, this study is informed by and acknowledges the work of Bettelheim (1991) and Marina Warner (2016); the monster, such as Michael Chemers (2017) and that of pantomime itself, including Taylor (2009). Finally, Marvin Carlson (2006) and his work on 'ghosting' allows for a frame of expectation of what and how an audience sees and does in a theatre space to be explored. By returning to these exponent's thinking through the lens of examining the pantomime monster, this paper argues that pantomime has a moral and ethical responsibility in the theatrical presentation of the 'other', whilst simultaneously giving a family a good night out at the theatre at Christmas.

\section{Act one, scene one: an historical context}

In 1716, John Weaver first used the term 'pantomime' when referring to his staging of The Loves of Mars and Venus (Drury Lane Theatre, London) that contained a 'crocodile' as a grotesque monster 'where the Passions and Affections of the Mind should be expressed' (cited in Frow, 1985, p. 37). Even in the genesis of the British pantomime, Weaver (as producer, writer and actor) called for an outward expression of 'otherness' in physical form in order for his audience to share the same physical space with these creatures. Leaping to the present, crocodiles continue to be in use, notably in Peter Pan, produced as a pantomime in Britain from the 1990s utilising the plot and characters of J.M. Barrie's text. The marketing of one of the latest productions of Peter Pan produced by QDOS Pantomimes sees Captain Hook, played by actor Steve McFadden, battling with an oversized monstrous crocodile through the doors of the Orchard Theatre, Dartford for their 2019/20 production ${ }^{1}$ : Here, Hook (a monster in physical form), battles his demon, the Crocodile (a perceived monster by Hook). What is of interest in this relationship is that even Hook has his monstrous 'other'. For Hook, the crocodile (constructed as a monster by many human beings), becomes the audience's ally in defeating Hook. In Aladdin, the baddie Abanazar's fear is of those who are wittier and more intelligent than himself. Audiences expect when watching a pantomime to discover the baddy's Achilles Heel and then relish in the character's frustrations by vocalising their booing and hissing ${ }^{2}$ with glee. Marvin Carlson's notion of ghosting whereby 'the present [theatrical] experience is always ghosted by previous experiences and associations whilst these ghosts are simultaneously shifted and modified' (2006, p. 2) is in operation in this interaction: the audience's expectation is to quickly identify the 'other' and relish in their inevitable downfall and enjoy when obstacles defeat them. Audiences are ghosted by the past experiences of the genre: it is a tradition handed down where adults who take children to their first pantomime explicitly teach the traditions that have ghosted the form of relevant call and responses, especially that of booing and hissing the baddie.

The most popular of current pantomime plots have been mainly reworked and modified from the folk tales and subsequent written fairytales of the Brothers Grimm (Snow White), Charles Perrault (Cinderella, Sleeping Beauty, Puss in Boots) and the Arabian Nights (Aladdin). These plots continue to be emulated by 
contemporary pantomime writers, yet how they are told changes dependent on the needs and interests of the writer, the venue, the audiences and any house styles of the producers. Since George Coleman's 1754 call to arms suggesting 'that the writers of pantomime should abandon the classical myth or legend as the subject of their openings and take a look instead at some Old Garland, Moral Ballard, or Penny History Book' (Frow, 1985, p. 109), the fairytale started to become a major source for the pantomime writer from the 1780s. Perrault's collection of fairytale stories had been in English translation since 1729, and so Coleman's request supported the move away from the mythological stories as a base, to the utilisation of the fairytale for the first part of the pantomime-which was story driven-and played prior to the slapstick Harlequinade of the second half. The shift away from myth to fairytale socio-culturally indicates a need or wish for a more hopeful future. Myths are typically punitive, with characters dominated by forces beyond the control of man. They ultimately are a battle with the Gods for our existence and the Gods can never be fully overturned (merely tamed) by man. Fairy tales, by contrast, are more concerned with emotion, feeling and the human capacity to change the outcomes of the story, which is crucial to its appeal. Myths which centre on gods and heroes have a superior quality that transcend man's ability to shape the world and the outcome of a myth. Myths often place demands on the audience to be more like the hero and achieve the heroic. In a myth, (hu)man will always be inferior to the hero and the divine. In contrast, fairy stories make no demands on the reader or audience, but rather offer signposts and symbolic meanings that point the receiver to a better self-determining humanity. From this perspective, the shift in focus of the pantomime narrative from the mythic to the folkloric resonates with the wider social, cultural and philosophical aspects and developments of the Enlightenment. In 1784, Kant asserted that the motto of the Enlightenment was 'dare to be wise' (2009, p. 1) and that the primacy and power of reason were necessary for courageous selfdetermination.

The monster in pantomime has also been personified or named in relation to cultural and social notions of 'otherness' as it moved into the $19^{\text {th }}$ Century. In 1854, the Giant of Jack and the Beanstalk was named 'Giant Russia' when produced at the Theatre Royal Manchester. A pervading threat from Russia was personified in and through the Giant, and moving forward to the 21st Century, the Oxford Playhouse's production of Jack and the Beanstalk (2017/18) named their giant Trump and was instantly recognisable as Donald Trump, $45^{\text {th }}$ President of the United States of America, in terms of physical features. Both of these instances see distance applied to the 'otherness' through their names (as well as through the use of giant puppetry in Steve Marmion's Oxford Playhouse production). For producer Paul Hendy of Evolution Productions, the use of the political in an appropriate way is a major component and that when the pantomime makes 'a political point, audiences really respond to that. Pantomime does evolve and you have to look at things differently each time' (Hendy, 2019, pp. 33-34), yet goes someway to distance his pantomimes from making an unbalanced political point, stating that 'it's quite interesting to see it a certain way if it's political and topical but it should be satirical. You cannot go too far or have too much political bias' (Hendy, 2019, p. 41). As this is an art form, there are naturally differing opinions of how to represent 'otherness', but where more overt political statements are made, evidence points to the use of the monster, Giant or Ogre roles to make that point, creating distance (and therefore humour) in engaging an audience. Satire is privileged as a device rather than overt commentary in ensuring that audiences do not see a political bias in the work for fear of alienating audience members. There is an expectation from both industry and audiences that pantomime can contain elements of satire whilst not being a satirical artform. When directing Beauty and the Beast (Halifax/Imagine Theatre 2019/20) a topically expected and popular reference to Brexit was delivered without it having a politically sided bias, with the comic character referencing that 'the people have spoken-we must act on it' as the audience cried 'encore' following a high octane comedy routine. In relation to satire and the monster, Taylor suggests that pantomime 'allows expression of popular feelings and ideas and sometimes the expression of politically incorrect sentiments' (2009, p. 138) yet the villain must always be defeated regardless of those sentiments. It is not therefore when they are defeated, but how. As the stories are known by an audience, I argued in an article for The Stage that the storytelling for the author and director therefore shifts towards focusing onto 'addressing how we tell [the story]' (Marsden cited in Sladen, 2018, p. 11) and how the monstrous is staged and defeated.

\section{Act one, scene two: the staging of evil and the monstrous}

Tracing the spatial dynamic between monster and audience to the English medieval and Renaissance stage and the staging of devils in the Mystery plays, there is a long-reaching historical antecedent to the staging of evil that informs and inspires spatial practices in the modern-day pantomime. Robert Weimann $(1978,2000)$ has contributed greatly to an examination of social hierarchies of space in the Renaissance theatre, identifying the locus space as the area of authority, 'spatially, socially and linguistically' (Weimann, 1978, p. 409) whereas the platea ('place') space houses the 'rules of decorum [and where] the language of privilege could be challenged or confronted' (Weimann, 1978, p. 410) alongside 'conventions of disguise, and of course, clowning, together with reminders of misrule and topsy-turveydom' (Weimann 1988, p. 410) where the use of an aside to the audience in Shakespeare's theatre would take precedence. The pageant wagon of Medieval drama became a natural locus, whereas the platea was often the 'ground around the wagon' (Taylor and Nelson, 1972, p. 121). The platforms and pageant wagons formed part of the locus, with the actors placed onto these wagons and where Heaven and Hell were represented, and the platea was the general playing area:

the 'place' [platea] was simply the area in front of the stage or scaffold [...] It was never geographically localised [...] Action itself told the story [...] The pageant wagon or scaffold would indicate the locus or loci of the action.

\section{(Kolve cited in Happe 1984, p. 64)}

Whilst Weimann presents the locus and platea as differing places of authority, Lin acknowledges an indebtedness to Weimann, yet argues that spatial conventions relate to social constructs and the interactivity that a character can have with their audience is thereby dependent on which part of the stage they occupy. Which characters occupy which space through the Medieval and Renaissance theatrical periods has had a direct impact on where characters are geographically situated on the contemporary pantomime stage. If, for Erika T. Lin, 'the platea embodies the subversive potential of popular performance' (2006, p. 285), then it is of no surprise that the traditions and rules of pantomime blocking ${ }^{3}$ in these two stage areas have been overtly informed or tacitly embraced by directors and performers from the Medieval staging. Entrances of the 'goodies' in pantomime (stage right) and the baddies (stage left) map onto the Medieval positioning of Heaven's pageant wagon to stage right and Hell Mouth on a stage left pageant wagon. Yet this is on a longitudinal scale. Latitudinal planes of pantomime are rarely discussed with 
the locus naturally upstage and the platea occupying the downstage area. The lower status characters (or the 'Everymans') of the Dame, Comic and Hero such as Aladdin or Jack often occupy the platea in the pantomime staging, engaging directly with the audience. As Lin argues, even though these are lower status characters (in relation to the Emperors and Kings), by being able to engage with the audience, 'the interactivity of the platea meant that characters with little social authority were, in fact, more theatrically privileged' (2006, p. 285). The family audiences of the modern pantomime are attracted to the Dame and Comic and their hero(s), engaging in their anarchic world to see how they combat the baddie and the monstrous other, who often occupy the geographic stage space of the locus. In practice, the frontcloth rises for an audience to see the Giant sitting upstage centre on a throne; the Wicked Queen is seen upstage on a dais or around her cauldron creating the spell to turn an apple poisonous, or Carabosse has her poisoned spinning wheel on an upstage turret or platform in Sleeping Beauty.

The grotesquery of these characters is moreover embellished with expressions of their inner motivations, which serve as clues to the audience of the deeper nature of what the dramatic struggle represents in symbolic and social terms. The Giant in Jack and the Beanstalk is often staged alongside a cage, which could be seen to represent his (note the masculine) desire for power and tyrannypotentially over women-as he imprisons the Princess. Moreover, these scenes are often staged in dimly lit, shadowy lighting states; a reflection that we are perhaps entering the world of the dark unconscious, the half-seen, or the undesirable. And we are encountering not just the monster as representation of the dark forces of the outside world but also those aspects of ourselves which we care not to accept or acknowledge. The staging, or eventual dramatic blocking of these elements on the more distant locus (i.e., farthest from the audience) further protects us from contact with dark societal and personal forces, and when they do advance towards us on the platea are met with hissing and booing, which could perhaps be seen as theatrical abstractions of evolutionary and animalistic expressions of warning and a prelude to attack.

For the audience, these semiotic clues provide cues as to what is really being struggled with and ultimately defeated in the pantomime. It is in one sense our own (unconscious) greed, desire to kill, dominate or destroy that is being overcome. For the audience to know that these forces can be defeated is reassuring, as they can leave the theatre satisfied that all can be well in the world. These characters, with assumed hierarchy, do not take a natural place on the platea and rarely interact with the audience. If they do, they consciously move downstage to occupy the platea, discussing their diabolical plans through a soliloquy on the apron stage, before moving back upstage into the locus area where they interact far less with the audience. In order to gain this theatrical privilege, they need to consciously move into the space of the clowns, heroes and the Every[wo]man. It ultimately weakens their supposed status, and the audience tacitly know this, feeling confident to boo and hiss through their licenced transgression. They remain a locus character but have to occupy the platea in order to access interaction with the audience, who are the natural allies of the goodies.

However, it is often the 'other' that makes its way into the theatrical space of contemporary pantomime through the platea before claiming a space in the locus. During my production of Dick Whittington (Halifax/Imagine Theatre 2013/14) the rats, arguably of lower social rank, entered through the audience, encompassing the platea, as did the Wicked Queen's evil spirits in Snow White at the same venue in 2018. Shrieks from audiences emerge as the 'others' enter through the auditorium, breaking any fourth wall and ensuring that the audience is complicit in the eventual support of helping our hero to rid the ordinary world from the monsters, devils and urchins who have transgressed into the safety of their space. The monsters interrupt their established (often idyllic) world. It is very rare in contemporary stagings of pantomime for the goodie characters to enter through the audience, especially the heroes (who rarely break the fourth wall). Numerous pantomimes see the Ugly Sisters of Cinderella arrive through the auditorium (Mitchell Arts Centre, 2018) but they are the comedy antagonists, thwarting our hero in her quest to escape a humdrum life. The Dame rarely enters through the auditorium, yet places him/herself onto the platea to connect with the audience:

Being watched and heard apparently puts one in the locus.

In the dynamics of sight and sound, it seems that platea

characters are the active doers of the action, and locus characters are the passive receivers of the action.

\section{(Lin, 2006, p. 290)}

Returning to the staging of Medieval drama, it was also the 'other' who occupied the platea. Devil characters mixed amongst the audience and within the streets of the Medieval drama as one of the Coventry Cycle plays contain the stage direction: 'here Erode ragis [rages] in the pagond [pageant] and in the street also' (cited in Beadle and Fletcher, 2008, p. 37). Herod, as the monstrous 'other', would be amongst the audience prior to arrival on stage: the threat becomes direct and, arguably, more tangible when sharing the same space as the audience who are longing and expecting for good to overcome evil. Returning to pantomime, when direct participation is required, the platea stage is often used to connect to and with the pantomime's final character: the audience. Here on the platea the comic tells us jokes, the hero asks us which way the baddie or monster was seen, and Peter Pan asks us to keep Tinkerbell alive and whether we 'do believe in fairies'? Audiences dutifully reply due to ghosted notions of the pantomime experience. In the case of Peter Pan there is a 'powerful component of reception' (Carlson, 2006, p. 96). If an audience does not dutifully reply, the characters of Pan and Tinkerbell in this moment are merely being watched and heard in the locus stage, unaware of our presence and there is an inability to change the course of the action. An audience's expectation is to change the course of events, and without this overt interaction, the piece remains a Christmas play as opposed to sitting within the genre of pantomime.

It is not only the spatial dynamics that owes debt to Medieval dramatic staging, but that of the heightened costuming and make up that often goes further than that of the 'goodies'. The Beast in Beauty and the Beast has a monstrous half or full mask and King Rat in Dick Whittington will be often made up with a greyed ghostly face, rat head and claws with rotting teeth and a frightening tail. Returning to the Medieval mystery plays, Alan J. Fletcher discusses that the N-Town Cycle had a 'farting devil [...] making funny the diabolical' (cited in Beadle and Fletcher, 2008, p. 200). The diabolical other is often heightened in order to emphasis an 'otherness', which in turn creates a distancing (the sprites of Snow White wore oversized cockroach costumes and the rats of Dick Whittington were overtly furry in their design for my recent Imagine Theatre productions). This distancing therefore places the threat at arm's length. The audience is able to tolerate these characters in their space whilst their heightened appearance semiotically can also provide humour. Directors and performers need to establish this, as otherwise if a child is too frightened they may leave the auditorium which alienates an audience, as opposed to the 'baddie' characters. The distancing allows for a negotiation to take place in staying complicit with the character's journey and to eventually witness good overcome evil. 
Actors playing the devil or other supernatural elements in Medieval drama, as per contemporary pantomime, also wore masks and were comical and representational in style. Baddies and monsters in the modern pantomime are masked, heavily made up, have bold wigs and headpieces or are represented by puppets which allows for a distancing and (whilst the baddies do not see themselves as comedic), can create opportunities for comedy and satire to emerge such as Giant Trump at the Oxford Playhouse discussed above.

The Times stated that it were a queer world and a sad if two and two were four inevitably and at all periods of the year; and if the impossible and the fantastic were not at epochs allowed to strut about in the guise of the possible and real' (cited in Frow 1984 , p. 186). The theatre has over its history, due to its live nature, mainly represented the staging of evil in the form of concrete personifications. Yet, the actual pragmatics of this staging has evolved. The monster, Ogre or baddie was often killed off, which occurs less frequently in contemporary manifestations of pantomime. Equilibrium is restored, with a return to the monomyth's ordinary world-but not for the monster. Traditionally they have been killed off and as producer Paul Hendy identifies, pantomime director and writer 'Suzie McKenna was ahead of the curve [not killing the giant] and I wouldn't now' (Hendy, 2019, p. 39) referring to the stage killing of the Giant who used to fall to its death (echoing the fairy story) following Jack's chopping down of the beanstalk as the Giant. I did kill off the Giant when last directing Jack and the Beanstalk in 2014/15 for Imagine Theatre at the Victoria Theatre in Halifax. Yet, when directing Snow White for the 2018/19 season at the same venue, questions arose as to the importance of allowing the Wicked Queen to have an opportunity for redemption. The staging of this became an enforced redemption with a spell backfiring on the Queen so that she was under a magical influence to be 'good' for eternity. Punishment was then seen to be undertaken on the Queen. Not killing off the monster echoes how some victims of violence call for justice to be served in the courts for their perpetrators, as opposed to not feeling that justice has prevailed if their perpetrator is killed or commits suicide. The final 'take home' moral message is important in relation to how children first negotiate their connection to the monstrous 'other', and then deal with their comeuppance or demise. It is to this that the next section turns its focus to.

\section{Act two: first negotiations with the monstrous as the pantomime audience becomes a complicit character}

Chemers argues that there is a paucity of texts concentrating on the monster in theatre as 'most scholars of the modern monstrous devote their energies to literary and cinematic achievements' (2017, p. 1). Whilst the roots of the pantomime story sink deep into both literary and fairytale traditions, pantomime is firmly positioned within the theatrical field. The monster, posits Chemers, can live in the shared space of the theatre; the audience breath the same air as the monstrous 'other' and therefore the vibrancy of the theatrical event means that there is a more immediate, sensory and visceral connection within this relationship. A child could potentially touch the monster, as well as seeing and hearing it. The theatre and pantomime is likely to be the first physical space in which children directly encounter a three dimensionally embodied heightened monster, which possesses an agency from the story within which they live and is not directly associated with their parents or care-givers in any way. Previous encounters with monsters are likely to have been through two dimensional books, or behind the safety of the on-off switch and a glass screen; or where parents or carers embody monsters to chase their children. In these latter encounters, the child is always aware that their parent is behaving 'as if they were the monster, but are not actually the monster. These early experiences developmentally prepare children to encounter increasingly fully and independently realised monsters both on stage and in life. Whilst the negotiation with the physically embodied monster is worked out in the theatre through the stage action, another internal negotiation is taking place in the mind of the child/audience mediated by the powerful relationship of the shared space between actor and audience.

The actors' playing therefore facilitates the child's/audience capacity to play and they are able to create and enter into what Winnicott (1971) conceptualises as a potential space: a psychological space described as the overlap of the play spaces between individuals and in this instance between stage and audience. This is a conceptual play space of possibilities and potential, in which struggles and conflicts can be played with, navigated and resolved without real world consequences. Here the child/audience can imagine both the best and worst outcomes of the encounter with the monster/other in a manner which is manageable and helpful for them. Many stories express such ideas to an audience or a reader and become the vehicle for receiving the unconscious projections of an audience. Stories do not only reflect society, but can shape a person's perspective and philosophies and reveal the chaotic nature of the world around us. Yet, they can also teach us new things and allow us to implicitly or explicitly explore ideas through their poetic parallel of life. As Andrew Simms argues,

folk tales emerge in times of upheaval, and from societies' grimmest moments. They enable us to process and assimilate extreme experience, and deal with our fears. They also, typically, communicate powerful and uncompromising moral narratives. It's not hard to draw a map of current major global problems with reference to them.

\section{(Simms, 2017)}

Taylor argues that creating distancing conventions in pantomime enables a safe negotiation as the tension or conflict is 'distanced from real contemporary experience to allow various interpretations rather than a single didactic presentation' (2009, p. 89). By creating a poetic stage parallel through the use of a fairytale as the framework for an anarchic pantomime experience, the 'otherness' belongs to a mythical or fairytale world, where an audience (and especially children) can feel safe to imaginatively and actively engage with combatting the evil 'other'. Distancing therefore creates safety.

The majority of contemporary pantomimes open with a framing device of good versus evil in the form of a prologue, whereby the baddie often encounters the goodie and the battle of the immortal characters begins. In my professional experience of directing over twenty five pantomimes, the battle between good and evil has always been set up within the first five minutes of the stage action and there is a cultural and ghosted expectation from an audience that both the goodie and baddie characters aim to get us on their side; the goodies invite us to cheer and the baddies invite us to 'boo' and hiss for their megalomaniacal plotting. Both sides therefore try to invite us into their story and negotiate our support, even though most children know the outcome of the story and therefore enjoy booing the baddie as their fate is tacitly known by all.

Producer Steve Boden of Imagine Theatre who produce fifteen professional pantomimes in the United Kingdom each Christmas states that,

It's really important that the audience get to see a physical representation of the ogre character, huge and grotesque. In the story the ogre has to transform into a lion or bear and a 
small mouse so it's really important that we create that effect clearly, simply and effectively for the audience. The same applies with any character like the Giant or Beast.

\section{(Boden, 2019)}

This enables the 'other' to have control over what they are seeing and experiencing as there is a tangible manifestation of a baddie sharing the same physical space. We are initially shocked as an audience, before tolerating their presence. The temporary screams and cries from the children in the auditorium of the first two scenes in pantomime as they meet the monsters segue into reactions of 'booing' and toleration that is part of the process of assimilation and accommodation of new and frightening experiences. Interestingly, the Giant will stay in the locus space, with his lower status henchman Fleshcreep often in the platea connecting to the audience. Imagine Theatre produced a new version of Puss in Boots for Coventry Belgrade Theatre for their 2019/20 Christmas season which meant that they had to morally negotiate how to present the Ogre in the story:

we set out to make the ogre a baddy. He bullies the town (a bit like the giant in Jack and the Beanstalk) so everyone understands that sometimes getting rid of a tyrant is one way to bring stability, but in the sense of panto, he becomes a victim of his own ability to transform and terrorise as different animals. By the cat simply getting him to transform into a mouse, a simple inevitable end is possible. We catch the mouse but don't necessarily have to kill it!

\section{(Boden, 2019)}

Stability and the return to the ordinary world for the heroes and 'goodies' is important in the denouement of pantomime, and a transformation for the Ogre ensures that the audience see alternative outcomes for the baddie as opposed only death.

David Pickering argues that in pantomime children are obsessed by the giant as a figure due to the fact that they delight in outwitting them as a giant 'derives from [an] identification [...] with their own parents (1993, p. 88). Children do delight in the giant or other monsters having their comeuppance or outwitting them, but never have I heard a child talking (seriously) about killing their parents! The shadow of the monster has to be overcome yet presented in a controlled way within the bounded safety of the theatrical action. Through a controlled and licensed transgression, the audiences are complicit in wanting Jack and his friends to climb the beanstalk to retrieve the stolen goods and the Princess. They also become complicit in the giant's eventual demise (whether death or redemption), often chanting with the onstage characters for Jack to 'chop' down the beanstalk that the Giant begins to descend at the end of Act Two. Yet there is a safety, due to the fated nature of the giant for the children who know the story: the giant must be defeated and so the inevitability allows for a licenced transgression to go against society's moral, cultural, religious, legal and ethical codes. In this case, we cheer for the heroes to chop down beanstalks and steal from these monsters. Secondly, the safety of the fairytale supports this choice. It is not a psychologically motivated realistic play as the archetypes of the anarchic world ensures that any monster's demise is not real and any metaphorical demises or comeuppances can be played out within the conventions of the theatrical event. A child is thereby enchanted by a good story, but also the pantomime has 'suggest[ed] solutions that perturb him' (Bettelheim, 1991, p. 20). Through the distancing in pantomime, the child is able to play out solutions as they deal with the monstrous other. If the pantomime does not kill off the monster, then the child is able to see alternatives to life's problems which are not as extreme and the 'child must be helped to make some coherent sense out of the turmoil of his feelings' (ibid: 5). The 'other' remains present in some shape or form if they are not killed off, ensuring that children know that the real world is not a saccharin place: there is always danger lurking in the background to be negotiated. Children's playwright and director David Wood states that the 'theme of justice is important to children [...] they become emotionally involved when a character is being treated unfairly' (cited in Bennett, 2018, p. 110). The children are negotiating how they deal with justice being served through the pantomime experience.

Playing out possible and realistic alternatives in drama and theatre, such as Boal's theatre of the oppressed whereby his technique of the 'Cop in the Head' (1995, p. 136) sees a person's 'fears, desires and phobias' (ibid: 137) personified. When they have been personified by another actor, changes are explicitly rehearsed by and played out in order to explore concrete and real world possibilities as a 'dress rehearsal of the actual act [as the rehearsal cannot be] impossible to realise in practice' (Boal, 2002, p. 260). The audience in pantomime sees and experiences how they can play out encounters with the other. In Aladdin, they naturally shout out to their heroes not to be duped by a disguised Abanazar who tries to trick them to swap an old, dusty (yet magical) lamp for a new one. We experience our heroes falling into a moral trap of judging a book by its cover; in this case a new material good is worth more than an older counterpart. Similarly in Snow White, the audiences scream to the titular character not to take the (poisoned) apple from the disguised Wicked Queen. Children are projecting their understanding of not speaking to and taking gifts from strangers in that moment of complicit integration.

The Ogre and the giant may be expressionist in their design, yet the events and story beats that surround them must have a basis in the reality of the child's life experience, and explore alternatives to the binary of 'kill or let live', which is more nuanced than the binary 'good versus evil' starting point of the pantomime prologue. As the pantomime story progresses, this binary collapses somewhat, as the events of the story allow for nuance and subtlety leading towards the eventual finding of 'temporary and permanent solutions to pressing difficulties' (Bettelheim, 1991, p. 6) which, in the pantomime, means defeating the 'other' in some way. As discussed above, there is a change for the monster or the baddie (they are defeated, yet the immortals (such as the fairy) often remain the same at the end of the pantomime, which supports Bettelheim's notion that 'the more simple and straightforward a good character, the easier it is for a child to identify with it and reject the bad other' (ibid: 10). The fairies, comics and dames are all simple and straightforward: they exist to provide the good anchor and for entertainment. The baddies are often more difficult to logically understand or comprehend, as their motives are often blurred as to why they are behaving in a certain way. Carabosse, the wicked fairy in Sleeping Beauty, often cites her motive for ensuring that the Princess pricks her finger on a spinning wheel on her 18th birthday is that she has been slighted by the King when overlooked to attend Beauty's christening. A child finds the logic of this difficult to swallow as the punishment does not fit the crime. No wonder they side with good and reject the monstrous and delight in booing and hissing. The pantomime therefore becomes an implicit theatrical vehicle as a 'tool for human education, selfawareness, and empathetic connection' (Chemers, 2017, p. 4).

\section{Epilogue: ethical decisions of actors, directors, writers}

Against the backdrop of the above, the moral positions of the characters are important in pantomime and it is incumbent on 
writers and directors to consider the presentation of the 'other'. With over 250 professional productions in the United Kingdom during the 2019/20 pantomime season (not including numerous amateur and community productions), how this is achieved remains contentious. Simon Sladen in his article Let's rejuvenate panto with fresh traditions for the modern age for The Stage forefronts notions of 'otherness' in relation to the fact that historically panto 'captur[ed] the sentiment of their day [...] women parodied, whiteness lauded and other cultures depicted as uneducated, simple and in need of British intervention' (2019, p. 10). As pantomime continues to evolve in relation to how writers and directors tell the genre's stories, so too does the way in which creative teams reflect and also potentially present how we deal with the monstrous. What has rarely changed since the early pantomime is the simplicity of the 'good over evil' (baddie/other) polarity and the basic story structure remains such:

i. there is always a quest or a journey for the hero;

ii. there is a rite of passage for the hero and a fundamental change following the defeat of the 'other';

iii. The 'other' is always defeated and the hero is always victorious (good always triumphs over evil);

iv. There is an acceptance by the ordinary world community of the changes in the hero following these defeats (such as how the townsfolk positively respond to Dick Whittington after his defeat of King Rat).

These are the immovable events in the plot structure: pantomime can reinvent itself but only within a certain frame; the boundaries are clear. It is less of a reinvention, and more of a refreshing. Tinuke Craig, director of Cinderella (Lyric Hammersmith 2019/20), ensured that her Cinderella was not merely an infantilised heroine in need of a Prince, but found a balance between the telling of the story and contemporary presentations of the feminine. Whilst making certain that her audiences realised that women do have an equal societal place as men, she wanted her them also to sense that Cinderella can enjoy the feminine without this being in anyway a weak position. It is the given circumstances of how the monstrous Wicked Stepmother and the stepsisters treat Cinderella that weakens our protagonist, regardless of gender:

The ultimate aim, Craig feels, is to acknowledge that "girly things are good-celebrating a fluffiness and a candyflossness" without pushing it on girls and, equally, to "get better at enjoying when our boys like pink". At the heart of their show is a "feisty scientist Cinderella who can also rock a beautiful ball gown".

(Waugh, 2019)

As noted, whilst until recently the original fairytale of killing the Giant in Jack and the Beanstalk was followed by pantomime writers, the current trend is for Jack not to kill the monster. Seasoned pantomime writer and director Suzie McKenna led the way for this trend and has been explicit in finding other ways to deal with her 'baddies'. She does not kill them and found it a struggle to do so from her 2005 Hackney Empire production of Jack and the Beanstalk onwards: 'I don't kill off any characters in my pantomimes, either. We have enough kids killing each other on the streets, thanks. We don't need to glorify that. There's always a better way' (Derrick, 2018). Critic Lyn Gardner missed the traditional denouement in McKenna's 2005 production, stating whilst she can 'understand why McKenna didn't want to kill off her giant (a monster of theatrical invention), it rather robs the story of a satisfying resolution' (Gardner, 2005). Hendy argues for the continual evolution of pantomime and how to deal with the monster's comeuppance:
Pantomime has changed. It has to evolve; we [the production company] are called Evolution for a reason. Pantomime doesn't have to be behind the curve but should be on it or in front of it. We've not done Jack and the Beanstalk for four years but the next time we do it I think we will have a different take on how the giant is done. Traditionally the Giant steals the harp but then Jack goes up and kills him! It's a little harsh. Four years ago, I wouldn't have given that a second thought: that's the story. Yet when we do it again, I will give it more consideration of what the Giant does and he'll probably have some form of redemption and to make him good again. Pantomime is reacting to what is happening today.

\section{(Hendy, 2019)}

To conclude, pantomime as a genre is not showing any signs of slowing down. Its monsters will remain a central part of the story and children will therefore continue to engage and navigate their relationship with the 'other' in the same space as the characters that personify evil, even though they are distanced on the locus stage. The 'ghosting effects of performance sequences' (Carlson, 2006, p. 111) means that the core components of pantomime's story structure (good overcoming evil or the interaction) that repeatedly occur will not shock the audience, due to the conscious recycling of pantomime tropes, yet how writers and directors tell that story should continue to surprise and engage. Cultural and social references will also change how the story is recycled yet evolutions such as McKenna's to the fate of the 'other' also reflects the changing moral, social and ethical movements of our time. In the case of the Giant, redemption and restorative justice has begun to take precedent in opposition to the original fairy story. Redemption and restorative measures are at the core of the British justice system. Britain, of course, will continue to be the home of pantomime and therefore pantomime must continue to find ways to hold a mirror up to nature.

\section{Data availability}

Not applicable as no datasets were generated or analysed.

Received: 30 November 2019; Accepted: 27 January 2020; Published online: 03 March 2020

\section{Notes}

1 https://www.newsshopper.co.uk/news/17937075.youve-got-let-laughs-roll---stevemcfadden-playing-captain-hook-dartford-panto/.

2 Booing and Hissing are part of the theatrical conventions of pantomime. Audiences are encouraged to vocalise their reacting, which 'announces the independence of the audience's knowledge, the autonomy of its tasks, the freedom of its will, and its internal exteriority to performance'.

3 Blocking is the term used for the positioning of actors in the stage space.

\section{References}

Beadle R, Fletcher AJ (eds) (2008) The Cambridge Companion to Medieval English Theatre, 2nd edn. Cambridge University Press, Cambridge

Bennett S (ed) (2018) Theatre for Children and Young People. 50 years of professional theatre in the UK. Aurora Metro Publications Ltd

Bettleheim B (1991) The uses of enchantment: the meaning and importance of fairytales. Penguin

Boal A (1995) The rainbow of desire: the boal method of theatre and therapy. Routledge, Oxon

Boal A (2002) Games for actors and non-actors. Routledge, London

Boden S (2019) Personal email interview with R Marsden. 9 September

Carlson M (2006) The haunted stage: the theatre as a memory machine. University of Michigan Press, USA

Chemers M (2017) The monster in theatre history: this thing of darkness. Routledge, London 
Derrick F (2018) Aladdin pantomime actor Clive Rowe and director Susie McKenna bring community spirit to Hackney Empire this Christmas. In: Your Area [online]. 15 November. https://www.inyourarea.co.uk/news/ aladdin-pantomime-actor-clive-rowe-and-director-susie-mckenna-bringcommunity-spirit-to-hackney-empire-this-christmas/. Accessed 26 Oct 2019

Frow G (1985) Oh yes it is! The history of pantomime. BBC Books

Gardner L (2005) Jack and the beanstalk. The Guardian [online]. 22 December. https://www.theguardian.com/stage/2005/dec/22/theatre1. Accessed 26 Oct 2019

Happe P (1984) Medieval english drama: a collection of critical essays. Palgrave, London

Hendy P (2019) Personal interview with R Marsden. 5 September

Kant E (2009) An Answer to the Question: What is Enlightenment. Penguin, London

Simms A (2017) We need new fairy stories and folk tales to guide us out of today's dark woods. 1 November. https://www.theguardian.com/commentisfree/ 2017/nov/01/fairy-stories-folk-tales-climate-change-refugees. Accessed 20 Sep 2019

Sladen S (2018) Why pantomime must be updated for the modern stage. The Stage [online]. 22 November. https://www.thestage.co.uk/opinion/2018/simon-sladenwhy-pantomime-must-be-updated-for-the-modern-age/. Accessed 26 Oct 2019

Sladen S (2019) Let's find creative ways to upend panto's gender imbalance. The Stage [online]. 21 November. https://www.thestage.co.uk/opinion/2019/ simon-sladen-lets-find-creative-ways-to-upend-pantos-gender-imbalance/. Accessed 26 Oct 2019

Lin TE (2006) Performance practice and theatrical privilege: rethinking Weimann's concepts of locus and plate. N. Theatre Q 22(3):283-298

Taylor J, Nelson AH (eds) (1972) Medieval english drama: essays critical and contextual. University of Chicago Press, Chicago

Taylor M (2009) British pantomime performance. University of Chicago Press

Warner M (2016) A short history of the fairytale. OUP, Oxford

Waugh R (2019) Director Tinuke Craig: 'Panto drives you-it wakes you up because it's so energetic'. 20 November. https://www.thestage.co.uk/opinion/2019/ simon-sladen-lets-find-creative-ways-to-upend-pantos-gender-imbalance/. Accessed 26 Oct 2019

Weimann R (1978) Shakespeare and the popular tradition in the theater: studies in the social dimension of dramatic form and function. Johns Hopkins University Press, USA
Weimann R (2000) Author's pen and actor's voice: playing and writing in Shakespeare's theatre. Cambridge University Press, Cambridge Winnicott D (1971) Playing and reality. Tavistock Publications, USA

\section{Acknowledgements}

Thanks go to Tim Fagan for contributing key ideas in the development of this paper.

\section{Competing interests}

The author declares no competing interests.

\section{Additional information}

Correspondence and requests for materials should be addressed to R.M.

Reprints and permission information is available at http://www.nature.com/reprints

Publisher's note Springer Nature remains neutral with regard to jurisdictional claims in published maps and institutional affiliations.

\section{(c) (i)}

Open Access This article is licensed under a Creative Commons Attribution 4.0 International License, which permits use, sharing, adaptation, distribution and reproduction in any medium or format, as long as you give appropriate credit to the original author(s) and the source, provide a link to the Creative Commons license, and indicate if changes were made. The images or other third party material in this article are included in the article's Creative Commons license, unless indicated otherwise in a credit line to the material. If material is not included in the article's Creative Commons license and your intended use is not permitted by statutory regulation or exceeds the permitted use, you will need to obtain permission directly from the copyright holder. To view a copy of this license, visit http://creativecommons.org/ licenses/by/4.0/

(c) The Author(s) 2020 